\title{
Teaching Children Foreign-Language Grammar: Are Authentic Materials Appropriate?
}

\section{Keywords:}

EFL classroom

grammar

authentic materials

children's books

young learners

intercultural communication 


\section{Abstract}

The paper discusses authentic materials as a resource for teaching grammar to young learners. Difficulties in foreign-language grammar learning for Russian pupils are presented, and typical challenges are described. The paper provides a pre-/post-intervention study of the development of children's grammar skills. The research question is, "How does one use authentic materials for teaching grammar in an English as a foreign language (EFL) classroom?" A qualitative method is used to assess the learning outcomes of using authentic materials in teaching grammar to eight-nine-year-old pupils (the second year of studying English). 


\section{Introduction}

Young learners of English as a foreign language face a great deal of problems in foreignlanguage grammar learning. For Russian pupils, they are (a) that they lack a language environment and (b) that some grammar categories do not coincide with the Russian language and others do not exist in it. This study has focused on the language potential of authentic materials, teaching grammar to young learners, and learning more about new cultures.

The paper discusses advantages and disadvantages of using authentic materials in an EFL environment and criteria for linguistic and contextual authenticity in educational texts, and it points out difficulties in selecting authentic materials. The research question is, "How does one use authentic materials for teaching grammar in an English as a foreign language (EFL) classroom?"

The paper starts by informing about the teaching of foreign languages in Russian primary schools. It discusses authentic materials in FLT (Foreign Language Teaching), the selection of authentic educational texts, and the use of authentic materials during educational intervention. The paper describes the methodology of research, presents the results of pre/post-intervention, and provides guidelines for using authentic materials in teaching foreignlanguage grammar to young learners.

\section{Teaching foreign languages in Russian primary school}

In Russia, English as a foreign language is compulsory in primary school. It is taught from the second grade in the school system. According to the year of studying, there are two or three English lessons a week in the curriculum. Nowadays, there is a great variety of books for teaching English to young learners. In Russia, only coursebooks recommended by the Ministry of Education may be used at schools in English lessons. Learning-support materials for teaching English in primary school contain subjects young learners should master and traditionally include the Teacher's Book, the Student's Book, the Student's Workbook, the Student's Grammar Workbook, the Reader, and audio materials.

In the Russian educational system, teaching grammar in a foreign-language context is compulsory at schools. Grammar is one of linguistic components in the curriculum, and grammar skills should be acquired in foreign-language learning (Rogova, Vereshchagina, \& Yazykova, 2008, p. 131). Even preschool children are taught grammar (Vronskaya, 2015, pp. 153-177).

Grammar knowledge is essential for competent users of a language (Harmer, 1991, pp. 1215). Very often, Russian students do not like grammar, and some of them are very anxious or even afraid of it. The first reason is that the language environment is limited in Russia. Eight-nine-year-old pupils (the second year of studying English) have only two English lessons a week at school. The other reason is that Russians have particular difficulties with English grammar. Some of what the young learners have to deal with in EFL classrooms are the verb "to be" in affirmative sentences, auxiliary verbs in negative and interrogative sentences, word order, verbs in the third person singular, which always have an s-ending in the present simple, articles, prepositions, and demonstrative pronouns. Some of these English grammar categories do not coincide with the Russian language, others simply don't exist in it. As grammar teaching is heavily emphasized in Russia, children have to perceive and understand grammar patterns taught in the lessons. Hence, in comparison with a more communicatively oriented approach to teaching foreign languages in European countries, a communicative-cognitive approach to teaching English to young learners is used in Russian primary schools (Rogova, Vereshchagina, \& Yazykova, 2008). 
According to Passov (1991), the core idea of the communicative approach is that the process of language acquisition should be organized as a process of real communication in a situational environment. The main objective of language teaching within this approach is communicative competence. Grigorenko and Sagalaeva (2014) mention that the basis of the communicative-cognitive approach is the cognitive mechanism, formation, development, and enhancement of knowledge necessary for a conscious acquirement of the language.

Because of these challenges, English language teachers in Russia need to make extra efforts (e.g., prepare additional learning material) to teach grammar to young learners. When one wants to arouse and maintain motivation and curiosity in elementary-school students, thoroughly selected authentic materials are of great value. They can make the process of learning grammar not only interesting and exciting but also relevant and enjoyable.

\section{Authentic Materials in Foreign-Language Teaching}

There are various definitions of the term "authentic materials." Harmer (1991, p. 205) refers to authentic texts as materials which are designed for native speakers; they are real texts, designed not for language students but for the speakers of the language. Azimov and Shchukin (1995, p. 34) consider authentic materials - oral and written texts - to be the real product of native speakers which are not meant for educational purposes. They are not adapted to students' level of proficiency and are characterized by the use of natural vocabulary and grammar forms. Azimov and Shchukin (1995, p. 34) also believe authentic materials to reflect national peculiarities and traditions regarding the forming and functioning of the language. Jordan (1997, p. 113) defines authentic texts as texts not written for teaching purposes. Authentic materials are significant since they increase students' motivation for learning and expose the learner to the "real" language, as explained by Guariento and Morley (2001, p. 347). Charlene Polio (2014, p. 2) considers authentic materials to be those that were not created for language-learning purposes. Instead, they were created with some real-life goal for native speakers.

The common feature of all these definitions is exposure to the real language with no thought given to non-native accessibility. Topics, language, structures, and so forth of authentic materials are oriented to native speakers and offered through various media intended for them.

Authentic materials have great advantages over other materials designed for the purpose of language learning. The main advantages of using them are the following:

- positive effect on learners' motivation,

- authentic cultural information,

- exposure to real language,

- correspondence to learners' needs,

- a more creative approach to teaching (Philips \& Shettlesworth, 1978; Clarke as cited in Richards, 2001).

Along with these advantages, there are some disadvantages of using authentic materials. They often contain difficult language, unneeded vocabulary items, and complex language structures (Richards, 2001). Martinez (as cited in Kilickaya, 2004) mentions that authentic materials may also be too culturally biased.

Traditionally, authentic materials are newspapers and magazines, advertisements, movie reviews, television shows, bills, receipts, menus, official letters, written notes and 
messages, conversations between native speakers, prescriptions and instructions, train schedules, labels and information on packages, and so on. Another type of authentic materials which should be mentioned is children's books (Polio, 2014).

\section{Children's Books in EFL Classrooms}

For young language learners, children's books are usually considered one of the most appropriate authentic materials in foreign-language learning. Children's books are impossible to imagine without pictures. There are many books for children, but not all of them are picture books. Sandie Mourão (2010, p. 1) distinguishes between picture books, illustrated books, and decorated books. The main similarity between them is that they all contain illustrations:

What makes a picture book different is the way the illustrations and the words combine in a book format. A true picture book tells the story both with words and pictures. The two narratives are important and the total format reflects the meaning of the story. All illustrated books usually include illustrations as extensions of the words, where the pictures are not necessary for its interpretation. A decorated book includes small pictures or designs, often at the beginning or end of a chapter. These decorations do not usually enrich or extend the story, merely decorate the pages. (Mourão, 2010)

The Caldecott Medal is a very prestigious medal in the world of children's literature. The Randolph Caldecott Medal Selection Committee annually recognizes "the most distinguished American picture book for children." It considers a picture book for children to be "one that essentially provides the child with a visual experience. It has a collective unity of story-line, theme, or concept, developed through the series of pictures of which the book is comprised" (http://www.ala.org/alsc/awardsgrants/bookmedia/caldecottmedal/caldecottterms/caldecottterms).

Sandie Mourão has also written a guide for teachers in Early Language Teaching (ELT) classrooms to using so-called "real books." This term is commonly used by teachers to refer to authentic books. It is interesting that Mourão also suggests the term realbook (Mourão, 2003). She claims that a realbook is highly motivating for all children, especially when they realize that with a little bit of English, they can do so much (Mourão, 2003, p. 4). The term realbooks sounds different for them in comparison with textbooks, coursebooks, or workbooks.

Many scientists study children's literature, examine the educational potential of children's literature, discuss ways of using picture books in EFL classrooms and the potential of children's literature for promoting intercultural education (Bland, 2013; Bland \& Lütge, 2013; Ellis \& Brewster, 2014; Ghosn, 2013; Ellison, 2010; Mourão, 2011).

Authentic texts are not intended for language training. However, the use of authentic materials in EFL classrooms is effective since they provide a natural-language environment and form necessary linguistic competence. This is what makes EFL teachers excited and willing to have authentic materials in their classrooms, but it is inevitable that they face the problem of book selection.

\section{The Selection of Authentic Texts}

Not all authentic picture books can be used as supplementary material in an EFL environment, as so-called real books have not been written specifically for primary English language teaching and the language is not selected or graded. "Many, however, contain examples of language traditionally found in syllabuses for children as well as "real" 
language, thereby offering a rich source of authentic input and challenge" (Ellis and Brewster, 2014, p. 14).

One of the most difficult aspects of using authentic materials with young learners is finding books that are interesting and appropriate for the students' level of proficiency in English. Many authors pay great attention to the selection of authentic texts (Nosonovich \& Milrood, 1999; Polio, 2014). Nosonovich and Milrood (1999) recognize that the selection of authentic texts in early language teaching should be approached with caution, as at this stage, the young learners have a limited vocabulary and understanding of grammar. As a result, very often, there is a need to adapt the text, which could lead to a breach of the principle of authenticity.

It is also necessary to select authentic picture books with reference to illustrations. Sandie Mourão (2010) recommends that one ask these questions:

- Are the illustrations synchronized with the text?

- Do the illustrations support understanding?

- Do the illustrations develop artistic perception and visual decoding skills?

- Are the illustrations appropriate for the age of the students?

- Are the illustrations attractive and colorful?

- Does the book's layout support children's understanding?

The selection of authentic texts should include a reference to criteria for authenticity. Nosonovich and Milrood (1999) distinguish between criteria for linguistic and contextual authenticity in an educational text. The criteria for linguistic authenticity in an educational text include the following: (a) structural authenticity-a close logical connection of the sentences; (b) authenticity of pronunciation (in audio and video materials)-retention of the natural speech of native speakers, its pronunciation, rhythm, and intonation; (c) lexicalphraseological authenticity-the diversity of lexical units, idioms, phrasal verbs, proverbs, and so forth; (d) grammatical authenticity-the use of grammatical structures peculiar to the foreign language, which reduces the probability of cross-language interference; and (e) functional authenticity - natural selection of linguistic means.

The criteria for contextual authenticity in an educational text are the following: (a) cultural authenticity-presence of lexical units with the national cultural meaning, which clearly show the peculiarity of the national culture; (b) informative authenticity-the presence of significant information that is interesting for young learners; (c) situational authenticitythe presence of different dialogues and speech patterns for behavior in various situations in everyday life; (d) authenticity of national mentality-taking into consideration the national identity of people; (e) reactive authenticity-the presence of expressive interjections, exclamations, and reinforcement structures in dialogues; and ( $f$ ) authenticity of execution (in audio and video material)-the presence of audio effects (traffic noise, passers-by conversations, phone calls, music, and so forth) which help one understand the nature of the circumstances or a special text design (newspaper clippings, greeting cards, and so forth).

An educational text should present an authentic discourse. Nosonovich and Milrood (1999) consider discourse to be the text-in-event-driven aspect. It is characterized by natural lexical content and grammatical forms and situational adequacy of linguistic resources and illustrates authentic use of the language.

An authentic educational text can be effectively used as a means of learning foreign language in primary school because (a) it activates the cognitive interests of young learners 
and thus increases their motivation for learning a foreign language; (b) it has a positive emotional impact on children; and (c) it immerses young learners in the socio-cultural environment of the country, its traditions, its way of life, and the behavior of people and introduces speech patterns used in various situations of everyday life. All these factors contribute to the development of communicative competence, which is the purpose of learning a foreign language.

\section{The Authentic Picture Book Green Eggs and Ham in EFL Classrooms}

Picture book written by the famous American author Dr. Seuss, Green Eggs and Ham, was chosen for the research. It was first published on August 12, 1960. The book is a part of American culture and it is so popular in the USA nowadays that Americans often cite it, Green Eggs and Ham parties are organized, and Green Eggs and Ham Cafés have been opened across the country, one of which is at the famous Universal's Island of Adventure in Orlando, Florida. The "green eggs and ham" topic can be found in everyday life in the USA. Merchandise for different age categories (toddlers, preschool children, schoolchildren, teenagers, and even adults) with pictures of the heroes and their phrases are common.

The book Green Eggs and Ham (Dr. Seuss, 1988) is about the relationships between children and adults and between beliefs and experiences. The main character, Sam-I-am, is trying to convince the unnamed character to try green eggs and ham. He spends the entire book trying not only to serve the dish in a number of different locations (in a house, in a box, in a car, in a tree, on a train, in the dark, in the rain, on a boat) but also with different characters (a mouse, a fox, a goat). Finally, after Sam's enormous attempts, the unnamed character agrees, tries green eggs and ham, and finds them delicious. Now he is ready to "eat them anywhere" and with anyone.

Lexical and grammatical features of the book make it appropriate for the use in FLT (Foreign Language Teaching) with students who have a limited proficiency in the target language. The book consists of only 50 words: a, am, and, anywhere, are, be, boat, box, car, could, dark, do, eat, eggs, fox, goat, good, green, ham, here, house, I, if, in, let, like, may, me, mouse, not, on, or, rain, Sam, say, see, so, thank, that, the, them, there, they, train, tree, try, will, with, would, and you. It contains the following repeated grammatical units: (a) grammar patterns: "Do you like ...? / I do not like ..." "Would you like ...? / I would not like ..." and "I will (not) ..."; (b) prepositions: in, with, and on; and (c) adverbs of place: here, there, and anywhere. The book contains the following lexical units: boat, box, car, dark, eggs, fox, goat, ham, house, mouse, rain, train, tree, green, good, and eat.

The book has bright, attractive, and colorful illustrations that are synchronized with the content of the text and support the understanding of it. The illustrations are appropriate for young learners and develop students' artistic perception and visual-decoding skills. Hence, the book's layout strongly supports children's understanding.

The authentic picture book Green Eggs and Ham also has a wide potential when it comes to teaching children intercultural communication. This is considered to be a form of communication that aims to share information across different cultures and social groups. Green Eggs and Ham satisfies all the criteria for linguistic authenticity in an educational text. As for structural authenticity, there are phrases ("Eat them! Here they are"). The book has supplementary material-the cartoon Green Eggs and Ham, which is based on the story of the book and was shot by CBN and DFE Films in 1973 in the USA. The natural speech of native speakers and intonation features of American English provide authenticity of pronunciation. The book contains a great variety of lexical and grammatical units that are continuously repeated in the text (lexical-phraseological authenticity). As for grammatical authenticity, there are phrases ("If you will let me be," "Here they are," and so forth). Functional authenticity is presented by phrases ("Would you like ..." "I do so like ..."). 
Green Eggs and Ham satisfies all the criteria for contextual authenticity in an educational text. The "green eggs and ham" topic is loved and popular among children and adults in the USA (cultural authenticity). Informative authenticity is provided by an unusual way of presenting information (in the form of a dialogue), by the use of an expressive design, and by a specific rhythm of narration. As for situational authenticity, there are phrases ("Would you like ..." "You will see," "Say!"). Teague (2006) and Balditsyn (2004) consider that features of the national mentality of Americans are freedom, equality, a strong aspiration for success and prosperity, pragmatics and enterprise, individualism and activity, and independence and optimism. According to Philip Nel (2004), the heroes of Dr. Seuss are optimistic, enterprising, and largely pragmatic. The main character of the book Green Eggs and Ham (Sam-I-Am) has national features of Americans-he is a man of action who strongly stands up for his beliefs (authenticity of national mentality). As for reactive authenticity, the text contains a great deal of expressive exclamations, such as "Say!" "I do!" "I do so like ..." and "Let me be!" The authenticity of execution is provided by the text designed as a dialogue and the cartoon Green Eggs and Ham, made in the musical genre, which can be used as supplementary material.

The importance of learning about a new culture in language education cannot be ignoredthe cultural aspect of using authentic picture books in the early language classroom is one of the most vital. The Russian Federal State Educational Standard for the Primary General Education (2009) states that it is necessary to use children's books for developing a friendly attitude and tolerance towards speakers of other languages. Picture books are useful in this regard because they acquaint young learners with other people's experiences, behavior, and beliefs. In this respect, picture books are almost ideal materials for teaching children intercultural communication.

Although using picture books in foreign-language education is not new, most of previous research is concerned with teaching primarily vocabulary and oral skills. It is obvious that vocabulary is the easiest aspect to focus on when using authentic texts, particularly when teaching young learners. This is partly because there is a great variety of activities that teachers can offer in an EFL environment for which students do not need to use much grammar or any listening-comprehension skills (Polio, 2014, p. 3). At the same time, using authentic texts for teaching grammar can show young learners how various structures are used and function in the language. Listening to the stories is the most authentic and popular activity (Pinter, 2006, p. 53). Dialogues and drill-like repetitions can lead to free dramatization and role-playing and can easily function as speech patterns. Green Eggs and Ham is a good example of an authentic picture book that can be used for teaching not only vocabulary but also grammar to young learners in EFL classrooms.

In this study, the aim was to investigate how this book, as an example of authentic material, can be used for grammar teaching for early language learners.

\section{Methodology of Research}

The research was conducted in 2012 at Herzen State Pedagogical University of Russia, the Department of Teaching Foreign Languages to Young Learners. The aim was to estimate the learning outcomes of the educational intervention for the development of children's grammar skills. Fifteen eight-nine-year-old students (the second year of studying English) from one of the schools in St Petersburg were involved: eight study participants (group 1) and seven pupils in the control group (group 2). All the pupils were from the same grade. At the beginning of their first year of studying English, none of the pupils had any foreign language experience, and they were assigned to the groups randomly. During the intervention, those groups were remained unchanged.

Before the educational intervention took place, the pupils of both groups were taught English according to the coursebook of Vereshchagina, Bondarenko, and Pritykina, English - 
2 (2009). Teaching materials used with this coursebook included the Teacher's Book, the Student's Book, the Student's Workbook, the Student's Grammar Workbook, the Reader, and audio materials. The Reader included adapted texts which did not satisfy all the criteria for contextual and linguistic authenticity in an educational text-they had only situational, structural, lexical-phraseological, and functional authenticity. Audio materials consisted of dialogues and some texts from the coursebook along with authentic songs, chants, and poems.

Pre- and post-intervention tests were used for data collection, with four weeks time span between them. They determined the level of children's grammar-skill development prior to the intervention and after it. To evaluate the actual impact of the intervention, pre- and posttest methodology was carried out in the control group (group 2) too, and a qualitative research method was used.

The pretest consisted of oral and written parts. During the oral part, special communicative situations in English were organized in which pupils demonstrated their knowledge of grammar patterns. The written part contained five sets of tasks on using already known grammar patterns, which were formulated in Russian. Each set contained 4 sentences-in general, pupils had to write 20 sentences. In sets 1-3, pupils had to translate sentences from English into Russian and from Russian into English using the grammar patterns "Would you like ...? / I would not like ..." (set 1), "Do you like ...? / I do not like ..." (set 2), and "I will (not) ..." (set 3). In set 4, pupils had not only to translate sentences but also to match with adverbs of place (here, there, and anywhere). In set 5, pupils had to insert prepositions (in, on, and with).

Authentic materials were not used at this school, so a special system of lessons for teaching grammar was developed, and educational intervention was conducted in group 1 . The picture book and the cartoon Green Eggs and Ham were included into the educational process (see the supplement for a detailed presentation of the lessons in the intervention). The intervention carried out in group 1 lasted for three and a half weeks and included 7 lessons which were all connected to the chosen book and the cartoon Green Eggs and Ham. The book and the cartoon were divided into six parts, and seven PowerPoint presentations were prepared. The lessons contained pre-watching discussions, watching of the cartoon, post-watching discussions, and activities, including various games (the "Here, there or anywhere" game, the "Guess what" game, and the Green Eggs and Ham board game). Specially-prepared worksheets and handouts with dialogues from the book were actively used. Individual, pair and group activities were implemented. The grammatical and lexical units in the book corresponded to the grammar and vocabulary of the coursebook, so pupils of both groups had the same grammar material to practice with. The pupils in group 2 were taught grammar according to the material of the coursebook by Vereshchagina, Bondarenko, and Pritykina, English - 2 (2009).

After the educational intervention, a posttest was conducted in both groups. Its aim was to estimate changes and assess the learning outcomes. Tasks related to the same grammar material in oral speech and written form were included.

\section{Results}

During the collection of data for evaluation of the pupils' grammar-skill development, each answer in the oral and written parts of the pre- and post-intervention tests was fixed. The results were calculated in the following way: $92-100 \%$ of correct answers gave 3 points, $74-91 \%$ gave 2 points, $60-73 \%$ gave 1 point, and less than $60 \%$ gave 0 points. Three levels of children's grammar-skill development were marked: high level (3 points; the pupil uses grammar patterns correctly), medium level ( 2 points; the pupil knows how grammar patterns are formed but makes some mistakes in using them), and low level (1 point; the pupil experiences difficulties in forming and using grammar patterns). In each group, the 
results were calculated in terms of the mean of the pupils' grammar skills development in oral and written language.

The results of the pretest in group 1 and group 2 are shown in Figure 1 and Figure 2 respectively.

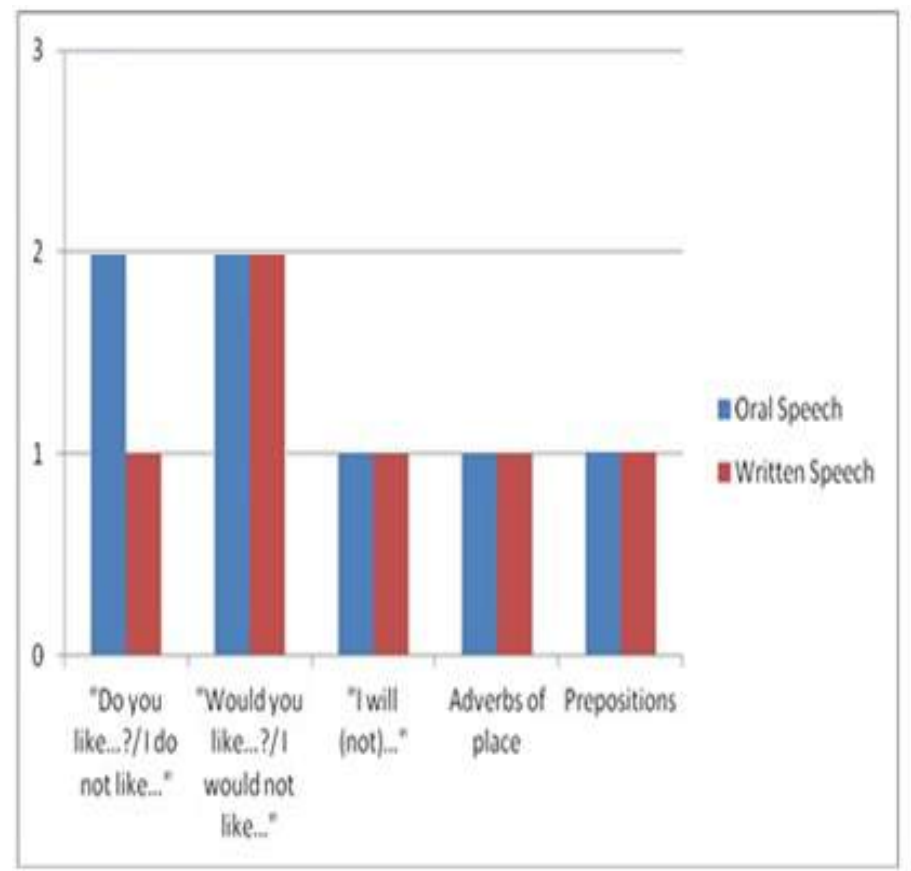

Figure 1

Pretest. Levels of grammar-skill development in group 1

( 1 = low level, 2 = medium level, and $3=$ high level).

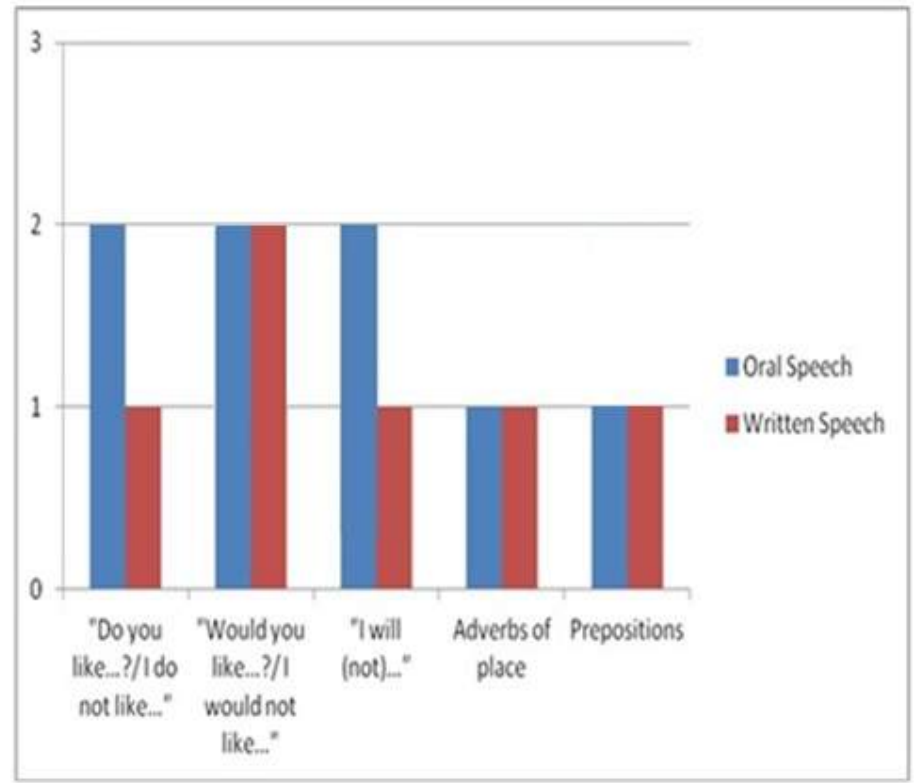

Figure 2

Pretest. Levels of grammar-skill development in group 2

( 1 = low level, 2 = medium level, and 3 = high level). 
They demonstrate a similar tendency: a medium level in the use of "Do you like ...? / I do not like" in oral language and a great deal of difficulties in written language (low level); a medium level in the use of the grammar patterns "Would you like ...? / I would not like ..."; a low level in the use of adverbs of place (here, there, and anywhere) and prepositions (in, on, and with) in both oral and written language. The pupils in group 2 demonstrated a medium level in the use of "I will (not) ..." in oral language and a low level in written language, while the pupils in group 1 showed a low level in the use of this pattern not only in oral language but also in written language.

Children made many mistakes when using the auxiliary verb do in the present simple in written language in both groups. This may be because oral language is easier than written language, as the teacher may help students non-verbally by gestures or facial expressions. Will in future simple caused a great deal of difficulties too. Auxiliary verbs (do, will) do not exist in Russian and are a serious problem for pupils. The medium level in the use of "Would you like ...? / I would not like ..." is due to a structural similarity in these grammar patterns between the languages. The low level in the use of adverbs of place can be explained by the fact that little attention is paid to them in the coursebook. Prepositions do not coincide in English and Russian-they are very difficult for pupils, and this is the reason for such a low level.

After the educational intervention, a posttest was conducted in both groups. The results of group 1 and group 2 are shown in Figure 3 and Figure 4 respectively.

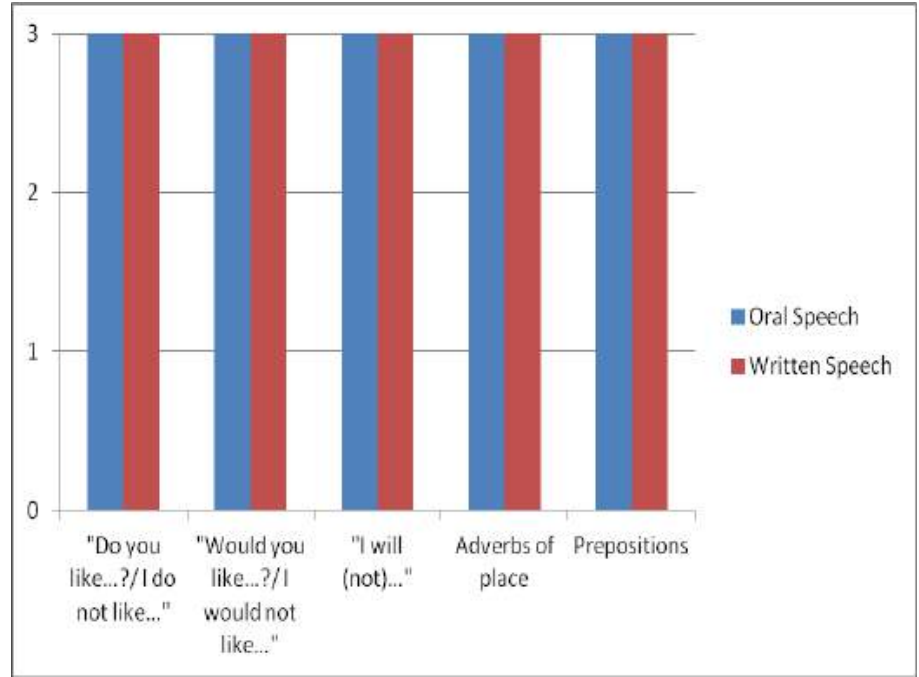

Figure 3

Posttest. Levels of grammar-skill development in group 1 ( 1 = low level, 2 = medium level, and 3 = high level). 


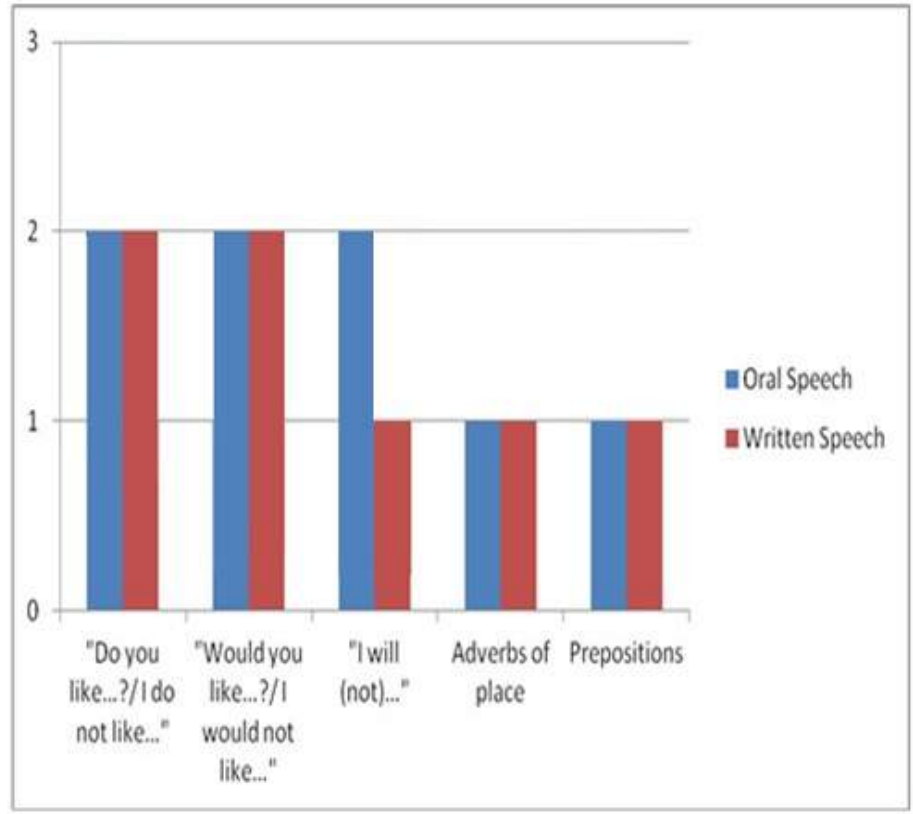

Figure 4

Posttest. Levels of grammar-skill development in group 2 ( 1 = low level, 2 = medium level, and 3 = high level).

All participants of group 1 demonstrated a high level of grammar-skill development with regard to the use of grammar patterns, adverbs of place, and prepositions in oral and written language (Figure 3). The pupils in group 2 progressed only with regard to the use of the pattern "Do you like ...? / I do not like" in written language (medium level) and showed no progress in other grammar material (Figure 4).

\section{Conclusion}

English is quite complicated for Russian students. It contains grammar categories which either do not coincide with those in the Russian language or do not exist in it. Hence, language teachers need to be competent and creative. Authentic materials are very effective, as they construct the natural language environment for young learners and provide natural language experience, and they are an efficient way of teaching intercultural communication.

The results of the intervention, teaching children grammar by means of authentic materials, were positive. Green Eggs and Ham is an authentic educational picture book which has great methodological potential, as it can be used for teaching not only vocabulary and oral skills but also grammar and intercultural communication to young learners.

1. The book corresponds to all the criteria for linguistic and contextual authenticity.

2. Grammatical and lexical units used in the book correspond to grammar and vocabulary learned by children in primary school in Russia.

3. Grammar patterns are constantly repeated throughout the text. The author of the book uses rhythmic patterns which contribute to involuntary memorizing of grammatical and lexical units. 
4. The book enhances cognitive processes and motivation, which lead to the promotion of communicative competence.

5. The book meets all the criteria for picture books concerning illustrations.

6. The use of the cartoon Green Eggs and Ham as supplementary material arouses children's interest in the book, the English language, and American culture. Thus, the book not only maximizes learning, teaches grammar, and entertains but also arouses and maintains children's curiosity, that extends to the language, people, and other cultures.

The research question was how authentic materials can be used for teaching grammar in EFL classroom. First of all, the picture book for young learners must be thoroughly chosen and examined. It should contain natural repetition and cumulative content which are attractive and suitable for children; grammatical and lexical units must correspond to the national curriculum; bright and colorful illustrations must be synchronized with the content of the text, support the understanding of it, and be appropriate for young learners; and the book must contain the potential for intercultural education and satisfy all the criteria for linguistic and contextual authenticity in an educational text. Secondly, a thoroughly developed system of lessons must be designed which includes various tasks, activities, and forms of work (individual, pair, and group work) and encourages young learners not only to join in the story and master the grammar but also to get acquainted with the culture of the target language.

It should be noted that this paper discusses only one authentic picture book. Thus, the limitation of the study is clear. Other authentic materials for teaching children grammar and intercultural communication can be selected and studied.

The paper examines advantages and disadvantages of the use of authentic materials in an EFL environment and the selection of authentic texts, considers the process of teaching grammar in Russia and the difficulties in foreign-language grammar learning for Russian young learners, studies the value of the book Green Eggs and Ham as a tool for teaching grammar and providing intercultural education, and demonstrates this book's methodological potential. The educational intervention has shown positive leaning outcomes of the use of Green Eggs and Ham by Dr. Seuss when teaching grammar to eight-nineyear-old pupils. 


\section{References}

Azimov, E. G., \& Shchukin, A. N. (1999). Novyi slovar' metodicheskikh terminov i ponyatiy [Dictionary of language-teaching terms]. Moscow: IKAR.

Balditsyn, P. (2004). Tvorchestvo Marka Tvena i natsional'nyi kharakter amerikanskoy literatury [The creation of Mark Twain and the national character of American literature]. Moscow: Publishing House BK.

Bland, J. (2013). Children's literature and learner empowerment. London: Bloomsbury Academic.

Bland, J., \& Lütge, Ch. (Eds.). (2013). Children's literature in second language education. London: Bloomsbury Academic.

Dr. Seuss. (1988). Green eggs and ham. New York: Beginner Books.

Ellis, G., \& Brewster, J. (2014). Tell it again! The new storytelling handbook for primary English language teachers. Retrieved from www.teachingenglish.org.uk/sites/teacheng/files/D467 Storytelling handbook FINAL web.pdf

Ellison, M. (2010). Make them think! Using literature in the primary English language classroom to develop critical thinking skills. E-F@bulations 7 Dez 2010. Retrieved from http://ler.letras.up.pt/uploads/ficheiros/8664.pdf

Ghosn, I. (2013). Storybridge to second language literacy. The theory, research and practice of teaching English with children's literature. Charlotte, NY: Information Age Publishing.

Grigorenko, S. E., \& Sagalaeva, I. V. (2014). Osnovnyie polozheniya i kriterii kommunikativno-kognitivnogo obucheniya inostrannomu yazyku [Basis statements and criteria of communicative-cognitive training of foreign languages]. Pedagogical education in Russia, 8, 261-265.

Guariento, W., \& Morley, J. (2001). Text and task authenticity in the EFL classroom. ELT Journal, 55(4), 347-353. Retrieved from http://eltj.oxfordjournals.org/content/55/4/347.abstract

http://dx.doi.org/10.1093/elt/55.4.347

Harmer, J. (1991). The practice of English language teaching. Longman: Longman Handbooks for Language Teachings.

Jordan, R. R. (1997). English for academic purposes: A guide and resource for teachers. Cambridge: Cambridge University Press. http://dx.doi.org/10.1017/CB09780511733062

Kilickaya, F. (2004). Authentic materials and cultural content in EFL classrooms. The Internet TESL Journal, 10(7). Retrieved from http://iteslj.org/Techniques/Kilickaya-AutenticMaterial.html

Ministry of Education and Science of Russian Federation. (2009). Federal'nyi gosudarstvennyi obrazovatel'nyi standart nachal'nogo obshego obrazovaniya [Federal state educational standard for the primary general education]. Retrieved from http://xn--80abucjiibhv9a.xn--p1ai/документы/922

Mourão, S. (2003). Realbooks in the primary classroom. Mary Glasgow Scholastic. Southam: Mary Glasgow Scholastic.

Mourão, S. (2010). What's in a picture book? In S. Mourão (Ed.), Celebrating ten years of teaching children in Portugal. APPI: Lisboa. Retrieved from

http://sandiemourao.eu/pages/images/Sandie Mour\%C3\%A30 2010.pdf

Mourão, S. (2011). Picturebooks for all. Retrieved from http://www.teachingenglish.org.uk/article/picture-books-all

Nosonovich, E. V., \& Milrood, R. P. (1999). Parametry autentichnogo uchebnogo teksta [Criteria of the authentic educational text]. Foreign Languages at School, 1, 11-18. 
Passov, E. I. (1991). Kommunikativnyi metod obucheniya inoyazychnomu govoreniyu [The communicative method of teaching foreign speaking]. Moscow: Prosveshcheniye.

Philip, N. (2004). Dr. Seuss: American icon. New York and London: Continuum Publishing.

Pinter, A. M. (2006). Teaching young language learners. Oxford: Oxford University Press.

Polio, C. (2014). Using authentic materials in the beginning language classroom. CLEAR News, 18(1). Retrieved from http://clear.msu.edu/clear/files/1314/0078/8342/2014-Spring.pdf

Richards, J. C. (2001). Curriculum development in language teaching. Cambridge: Cambridge University Press. http://dx.doi.org/10.1017/CBO9780511667220

Rogova, G. V., Vereshchagina, I. N., \& Yazykova, N. V. (2008). Metodika obucheniya angliyskomu yazyku. 1-4 klassy: Posobiye dlya uchitel'ey i studentov pedagogicheskikh vuzov [Methodology of teaching English 1-4 forms: A guide for teachers and students of pedagogical universities]. Moscow: Prosveshcheniye.

Teague, G. (2004). USA - culture smart! A quick guide to customs \& etiquette. Great Britain: Kuperard.

Vereshchagina, I. N., \& Pritykina, T. A. (2009). Angliyskiy yazyk 2 klass. [English 2. coursebook]. Moscow: Prosveshcheniye.

Vronskaya, I. V. (2015). Metodika rannego obucheniya angliyskomu yazyku [Methodology of early language learning]. St Petersburg: KARO. 


\section{Supplement}

\section{Green Eggs and Ham for teaching grammar to young learners}

\section{Lesson 1}

\section{Aims}

- To get acquainted with the main heroes of the book Green Eggs and Ham

- To introduce the construction "Sam-I-Am"

- To complete the "My Visiting Card" worksheet

\section{Materials}

- Interactive whiteboard

- The book Green Eggs and Ham

- The cartoon Green Eggs and Ham (part \#1)

- Screenshots from PowerPoint presentation \#1 (PPP \#1)
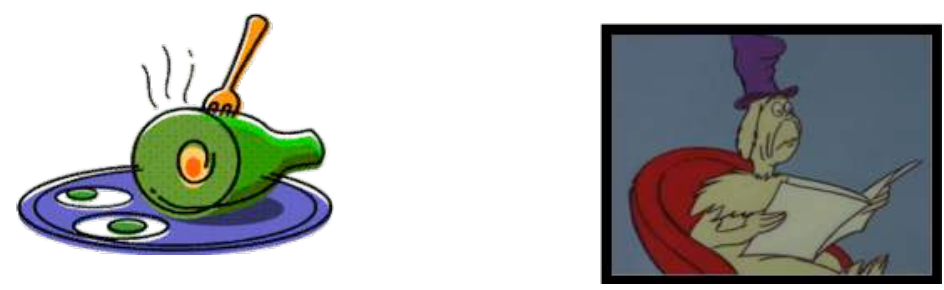

His name is... Sam-I-Am!

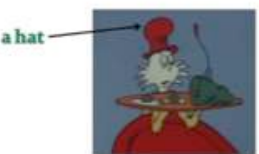

- "My Visiting Card" worksheet for each child

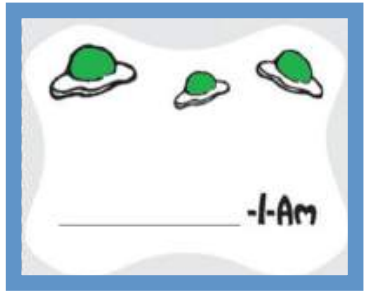

- Crayons 


\section{Introducing the story}

\section{- Pre-watching discussion}

Ask your pupils, "Do you like cartoons / Are you fond of cartoons?" Tell the children they are going to watch the cartoon Green Eggs and Ham. Show the screenshot of green eggs and ham, and say, "Look! What are these?" Encourage the reply "green eggs and ham." Show the screenshot of Sam in the hat, and say, "Look at this person. What color is his hat?" (Answer: red.) Ask the following emotional question: "Do you like him?" Let children watch the cartoon Green Eggs and Ham (part \#1). Give the pre-watching task of finding out what his name is.

- Watching of the cartoon (part \#1)

- Post-watching discussion

Encourage the answer to the pre-watching task "Sam-I-Am." Praise children, and tell them that usually, we introduce ourselves with "I am Olivia/Brad/Michael ..." Let the pupils play and change their names. Hand out the "My Visiting Card" worksheet to each child. Ask the pupils to write their names as in the example. Give them some time. Approach each child, and ask, "What is your name?" (Dima-I-Am / Rita-I-Am ...) Show the screenshot of a person with the newspaper. Suggest calling him Friend (let the screen-tip "Friend" appear on the screenshot). Ask the pupils to guess the favorite food of Sam-I-Am and Friend (children's guesses). Tell the children they will find it out soon from the cartoon and the book Green Eggs and Ham (show the book), and Sam-I-Am and Friend will help them learn English. 


\section{Lesson 2}

\section{Aims}

- To introduce the new grammar "Do you like ...? I like ... / I do not like ..."

- To introduce and/or revise the following words on the topic of food: bananas, apples, tea, milk, ice-cream, pizza, chocolate, fish, cheese, and hamburger

- To complete the "I like ... / I don't like ..." worksheet

\section{Materials}

- Interactive whiteboard

- The cartoon Green Eggs and Ham (part \#2)

- Screenshots from PowerPoint presentation \#2 (PPP \#2)
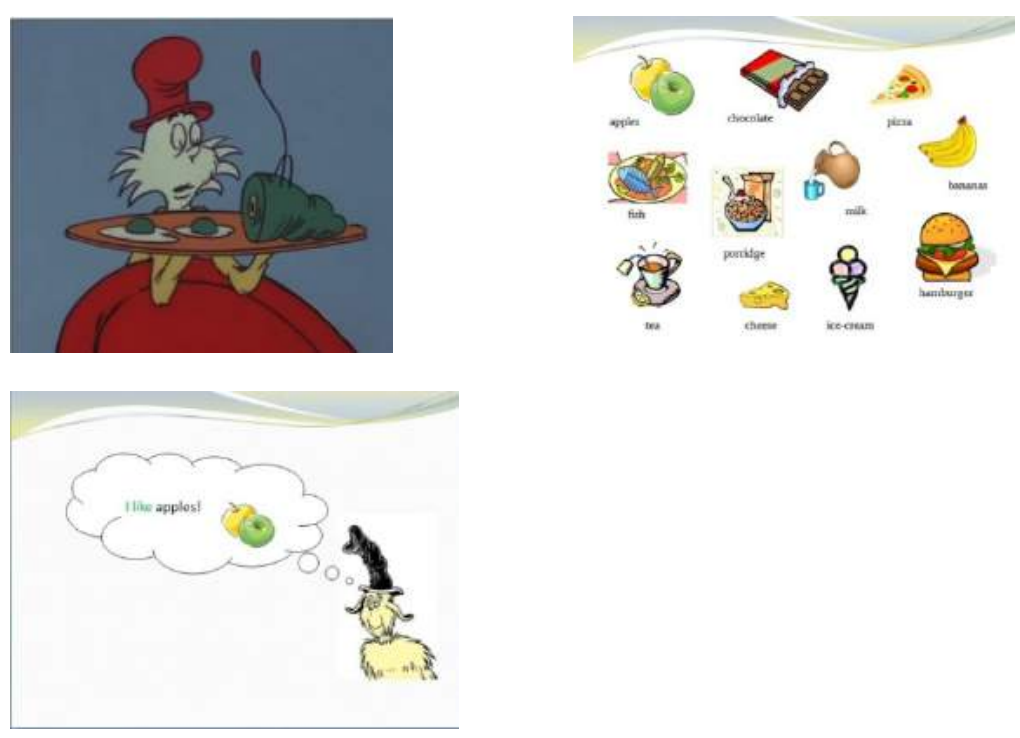

Sam-l-am:
I am Sam. Sam-l-am.
Friend:
That Sam-I-am! That Sam-I-am!
I do not like that Sam-l-am!
Sam-l-am:
Do you like green eggs and ham?
Friend:
I do not like them, Sam-l-am.
I do not like green eggs and ham.


- "I like ... / I don't like ..." worksheet for each child

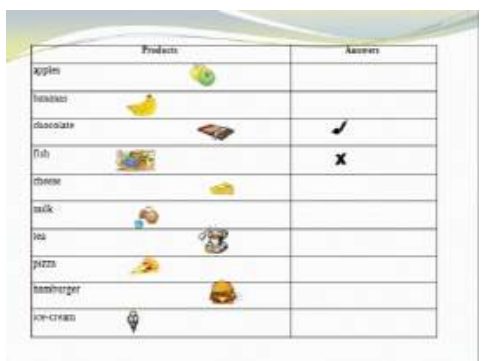

\section{Introducing and/or revising words on the topic of food}

Show a screenshot of Sam, and ask, "What is his name? What is his favorite food?" Encourage the replies "Sam-I-Am" and "green eggs and ham." Ask the children about food they know, and use the screenshot of food (bananas, apples, tea, milk, ice-cream, pizza, chocolate, fish, cheese, and hamburger). Encourage them to repeat words several times, together and individually, taking care they pay attention to the pronunciation.

\section{The grammar patterns "Do you like ...? I like ... / I do not like ..."}

- Pre-watching discussion

Show a screenshot of Friend dreaming about apples, and ask your pupils, "Who is he? What are these?" Encourage the replies "Friend" and "apples." Say, "Friend likes apples and tells us, 'I like apples."' Encourage them to repeat this phrase several times, together and individually, taking care they pay attention to the pronunciation. Let the children watch the cartoon (part \#2) and guess what it is about.

- Watching of the cartoon (part \#2)

- Post-watching discussion

Encourage the answer to the pre-watching question, "About Friend. He says, 'I don't like green eggs and ham.'" Watch the cartoon (part \#2) once more, stop the video each time the grammar patterns "Do you like ...? I do not like ..." appear on the screen. Be sure your pupils understand the meaning of these phrases. Show the screenshot of food and ask, "Ann-I-Am, do you like apples?" (I like apples / I don't like apples). Ask each child. Hand out the "I like ... / I don't like ..." worksheet to each child, and explain that they have to put a tick $(\sqrt{ })$ if they like or a cross $(x)$ if they don't like. Give them some time to fill it in, and fill in the same worksheet. Let the pupils ask you questions to find out your favorite food ("Do you like ...?"). Encourage the pupils to work in pairs, using the grammar patterns "Do you like ...? I like ... / I do not like ...."

\section{- $\quad$ Reading}

Show a screenshot of the text, and encourage the children to read it using role play. Pay attention to the pronunciation and intonation. Tell the pupils to practice role play at home. 


\section{Lesson 3}

\section{Aims}

- To introduce the adverbs here, there, and anywhere.

- To introduce the new grammar "Would you like ...? / I would not like ..."

- To introduce and/or revise the following words: house, table, bird, flower, tea, fox, tree, juice, ice-cream, and dog

- To complete the "Here or there" worksheet

\section{Materials}

- Interactive whiteboard

- The cartoon Green Eggs and Ham (part \#3)

- Screenshots from PowerPoint presentation \#3 (PPP \#3)
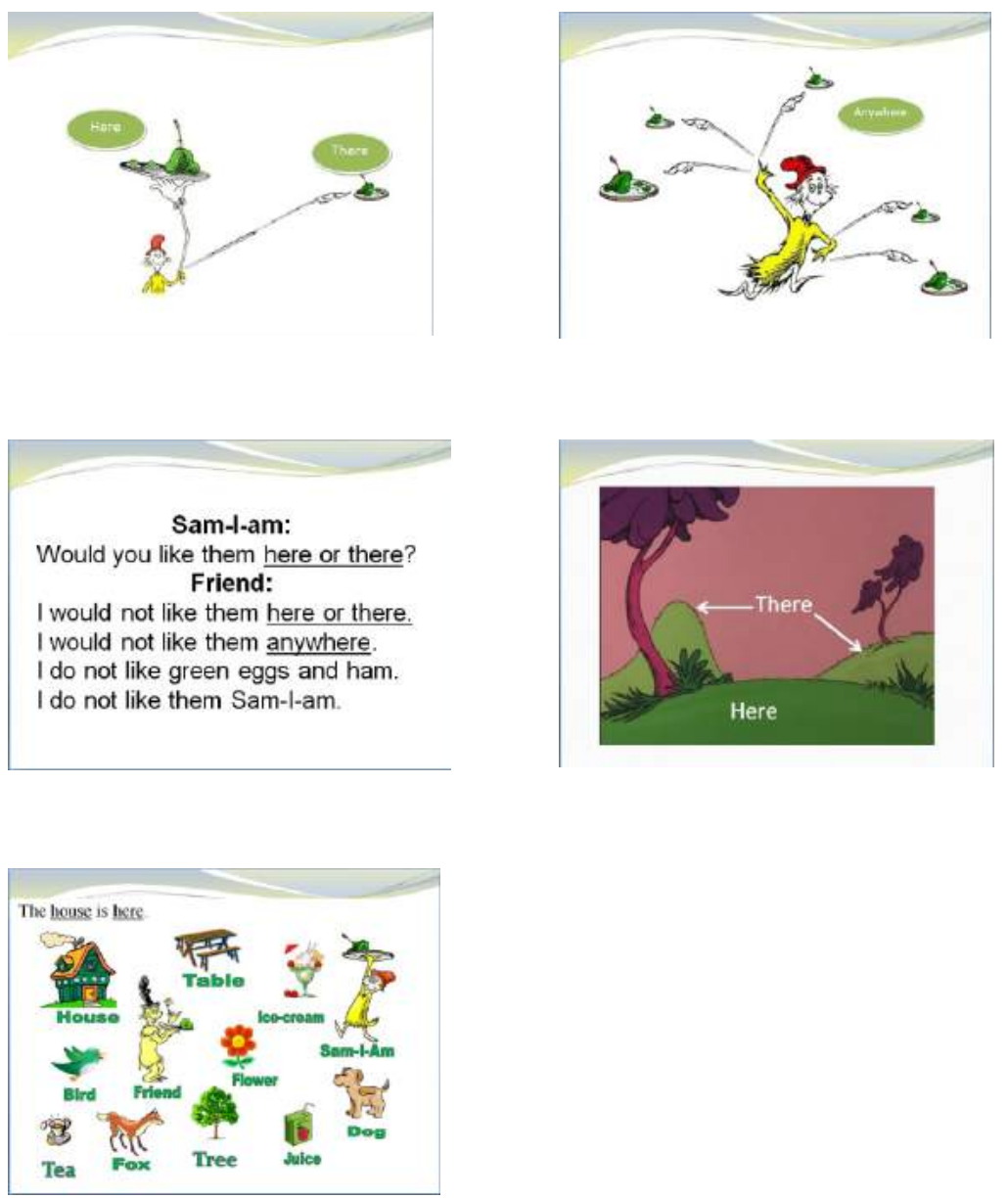
- "Here or there" worksheet \#1
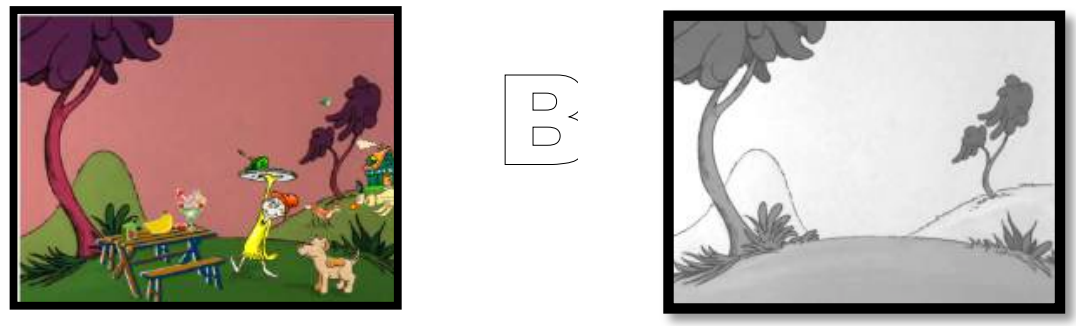

- "Here or there" worksheet \#2
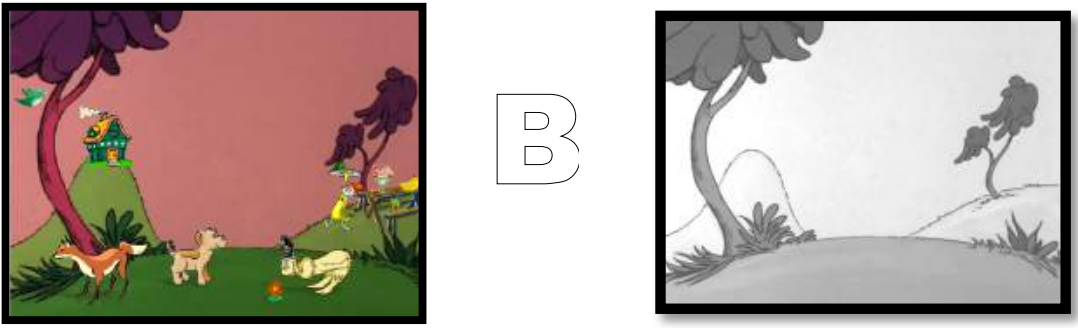

\section{The adverbs of place here, there, and anywhere and the grammar patterns "Would you like....? / I would not like..."}

\section{Pre-watching discussion}

Show the screenshot of a dialogue between Sam-I-Am and Friend from the previous lesson, and tell the pupils to role play it. Then ask, "Do you want to watch the cartoon?" Let the children watch the cartoon (part \#3) and find new words and phrases.

2. Watching of the cartoon (part \#3)

3. Post-watching discussion

Encourage the answer to the pre-watching task "Would you like ... / I would not like ..." and the words here, there, and anywhere. Watch the cartoon (part \#3) once more, and stop the video each time the adverbs (here, there, and anywhere) appear on the screen. Use screenshots with adverbs from the PowerPoint presentation (PPP \#3). Encourage the children to repeat the words several times, together and individually, taking care they pay attention to the pronunciation. Be sure your pupils understand the meaning of the adverbs and grammar structures.

Here/there activity

Show the screenshot with different objects from PPP \#3. Ask the children to describe it using here or there. ("The house is there. The fox is here," and so forth.)

The "Here, there, or anywhere" game

Ask the children, "Do you like to play?" Explain that they are going to play to practice new words. Put a sign saying "Here" on the desk that is near you and a sign saying "There" on 
the desk in the far corner of the classroom. Divide the children into two teams. Pupils from each team have to put things on different desks according to the task ("Put the flower there," "Put the bird anywhere," "Put the dog here," and so forth). If the pupil performs correctly, his/her team gets one point.

Hand out the "Here or there" worksheets. Let the pupils work in pairs, one child receiving worksheet \#1, the other child worksheet \#2. Each worksheet consists of pictures A and B. Each child has to describe objects from his/her worksheet (picture A) using here or there ("The table is here," "The house is there," and so forth), and the other child has to draw these objects on his/her worksheet (picture B) correctly. Let the pupils compare their pictures.

\section{Reading}

Show a screenshot of the text, and encourage the children to read it using role play. Pay attention to the pronunciation and intonation. 


\section{Lesson 4}

\section{Aims}

- To introduce the new grammar "Would you like ...? / I would (not) like ..."

- To introduce and/or revise the following words: ice-cream, apples, flowers, bananas, cheese, watermelon, green eggs and ham, kiwi, peach, candy, pizza, hamburger, chocolate, lemon, oranges, and carrot

- To complete the "Food" and "Would you like ...?" worksheets

\section{Materials}

- Interactive whiteboard

- The cartoon Green Eggs and Ham (part \#3)

- Screenshots from PowerPoint presentation \#4 (PPP \#4)
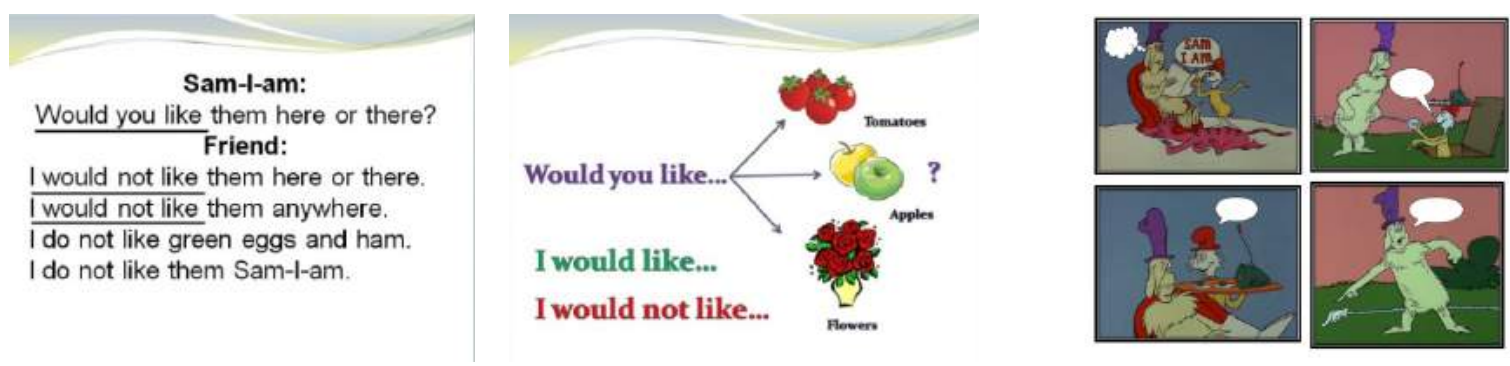

- The worksheet "Food"

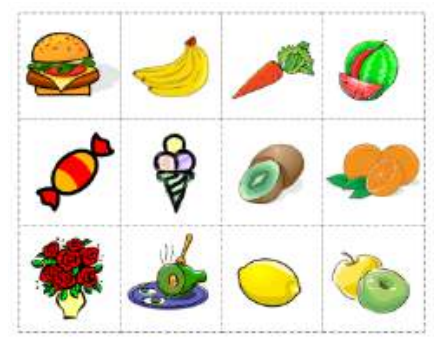


- The worksheets "Would you like ...?"
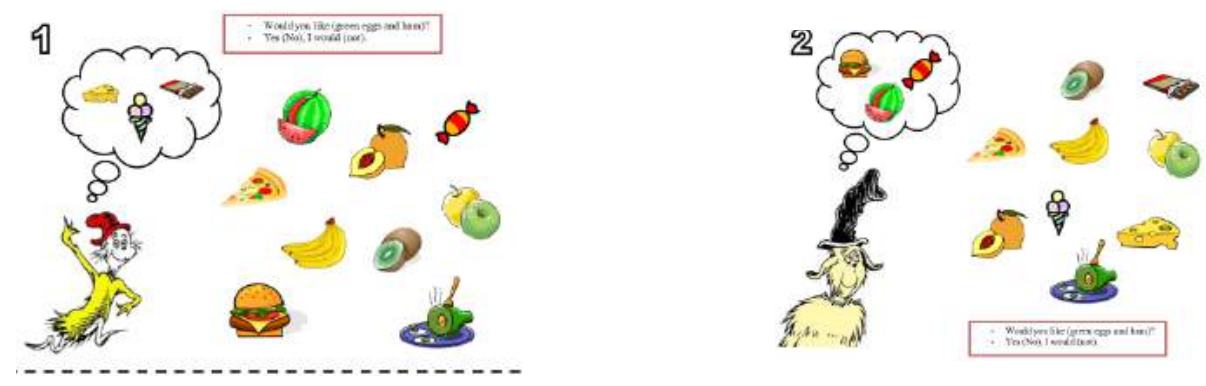

- Handouts with the dialogue for each child

\section{The grammar patterns "Would you like ...? / I would (not) like ..."}

1. Pre-watching discussion

Ask your pupils, "Would you like to watch the cartoon?" Let the children watch the cartoon (part \#3). Ask the pre-watching questions "How does Sam-I-Am offer food to Friend? What is his answer?"

2. Watching of the cartoon (part \#3).

3. Post-watching discussion

Encourage the answer to the pre-watching question "Would you like ...? I would not like ..." Show the screenshot of the dialogue from the previous lesson, and give handouts with the same dialogue to each child. Ask the pupils to underline the grammar patterns in their handouts, and do the same on the interactive whiteboard. Use the next screenshot of PPP \#4 with the patterns "Would you like ... / I would (not) like ...." Encourage the children to form and repeat phrases several times, together and individually, taking care that they pay attention to the pronunciation and intonation.

\section{Pairwork}

Hand out the worksheet "Food." Let the children ask each other questions and answer them. Hand out the worksheet "Would you like ...?" It consists of two parts-give part 1 (Sam-IAm) to one child and part 2 (Friend) to the other one. Say, "In the bubble you can see food your hero would like to eat. Find out the favorite food of your partner's hero. Use the structure 'Would you like ...?' If the answer is 'I would like ...,' circle the picture. If the answer is 'I would not like ...,' cross it out." Tell the children not to show their picture to each other.

The game "Guess what"

Show the last screenshot of PPP \#4. Say, "Guess the phrases in the speech balloons. Pretend you are professional actors. Provide the voice of one of the heroes from the cartoon Green Eggs and Ham. 


\section{Lesson 5}

\section{Aims}

- To introduce the new grammar "I would eat ... in ... with a ..."

- To introduce and/or revise the following words: in, with, house, mouse, car, star, box, fox, tree, bee, bat, hat, bed, and cat

- To complete the "Word Search" worksheet

\section{Materials}

- Interactive whiteboard

- The cartoon Green Eggs and Ham (part \#4)

- Screenshots from PowerPoint presentation \#5 (PPP \#5)
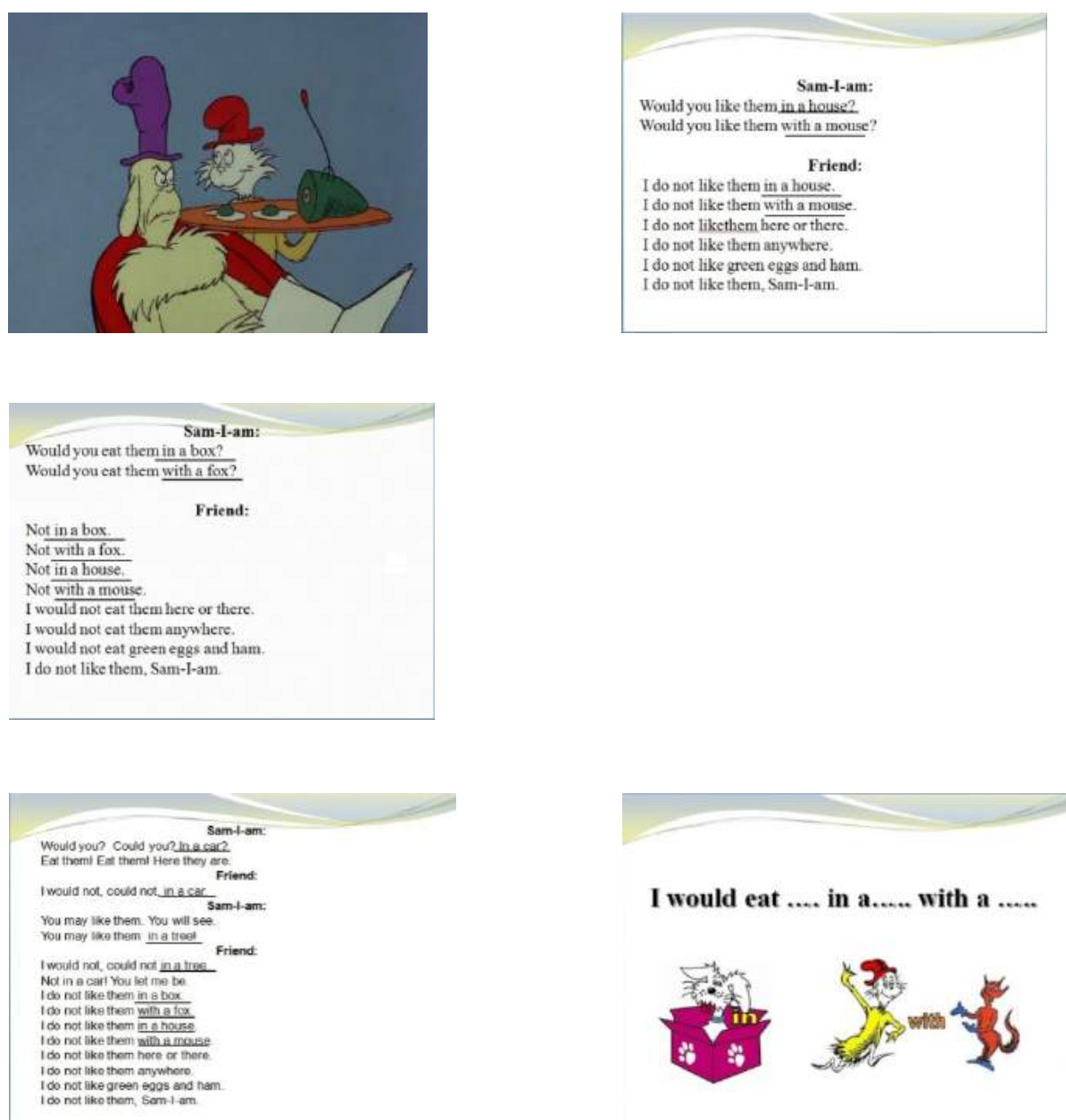

- Handouts with the dialogue for each child 
- The worksheet "I would eat ... in ... with a ..." for each child

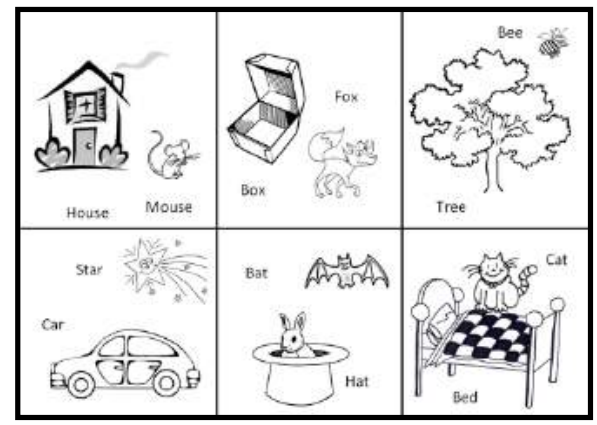

- The worksheet "Word Search" for each child

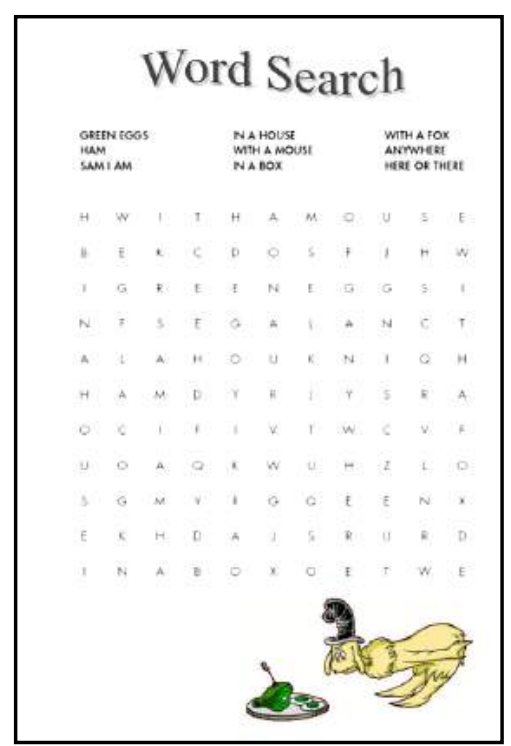

The grammar pattern "I would eat ... in ... with a ..."

Revise the material of previous lessons, the words on the topic of food, the adverbs here, there, and anywhere and the grammar patterns "Would you like ...? / I would (not) like ..." Organize your work in the form of a dialogue, or ask the pupils to translate sentences from Russian into English ("Would you like apples here?" "No, I do not like apples anywhere," and so forth).

\section{Pre-watching discussion}

Ask your pupils, "What would Sam-I-Am like Friend to eat?" (Answer: green eggs and ham). Let the children watch the cartoon (part \#4). Ask the pre-watching question "Guess the meaning of the prepositions in and with."

2. Watching of the cartoon (part \#4)

3. Post-watching discussion 
Encourage the answer to the pre-watching question in Russian. Be sure that your pupils understand the meaning of these prepositions. Let them watch the cartoon once more (part \#4). Say, "Clap your hands when you hear the words in and with."

\section{Reading}

Encourage the children to repeat prepositions several times, together and individually, taking care that they especially pay attention to the pronunciation of the preposition with. Show the screenshot of the dialogue from PPP \#5 on the interactive whiteboard, and give handouts with the same dialogues to each child. Ask, "Where and with whom does Sam-IAm ask Friend to eat green eggs and ham? Find the words in the text and underline them." Give the pupils some time to work individually. Check their answers ("in the house," "with the mouse," and so forth), and underline the same phrases in the screenshot. Let the children read them together. Divide your class into two groups-one group will be Sam-IAm and read his phrases, and the other will read Friend's phrases.

Show the last screenshot of PPP \#5 with the grammar structure "I would eat ... in ... with a ..." Ask, "Where and with whom would you like to eat green eggs and ham?" Hand out the worksheets "I would eat ... in ... with a ..." to each child. Ask, "Where and with whom would you like to eat your favorite food?" (for example, "I would eat pizza in a car with a star").

Hand out the worksheet "Word Search" to each child. Encourage individual work. 


\section{Lesson 6}

\section{Aims}

- To introduce the new grammar "I will eat ... / I will not eat" and the prepositions on, in, and with

- To introduce and/or revise the following words: car, bus, bicycle, plane, train, and boat

- To complete the "I would eat ... in ... with a ..." and "In/on" worksheets

\section{Materials}

- Interactive whiteboard

- The cartoon Green Eggs and Ham (part \#5)

- Screenshots from PowerPoint presentation \#6 (PPP \#6)
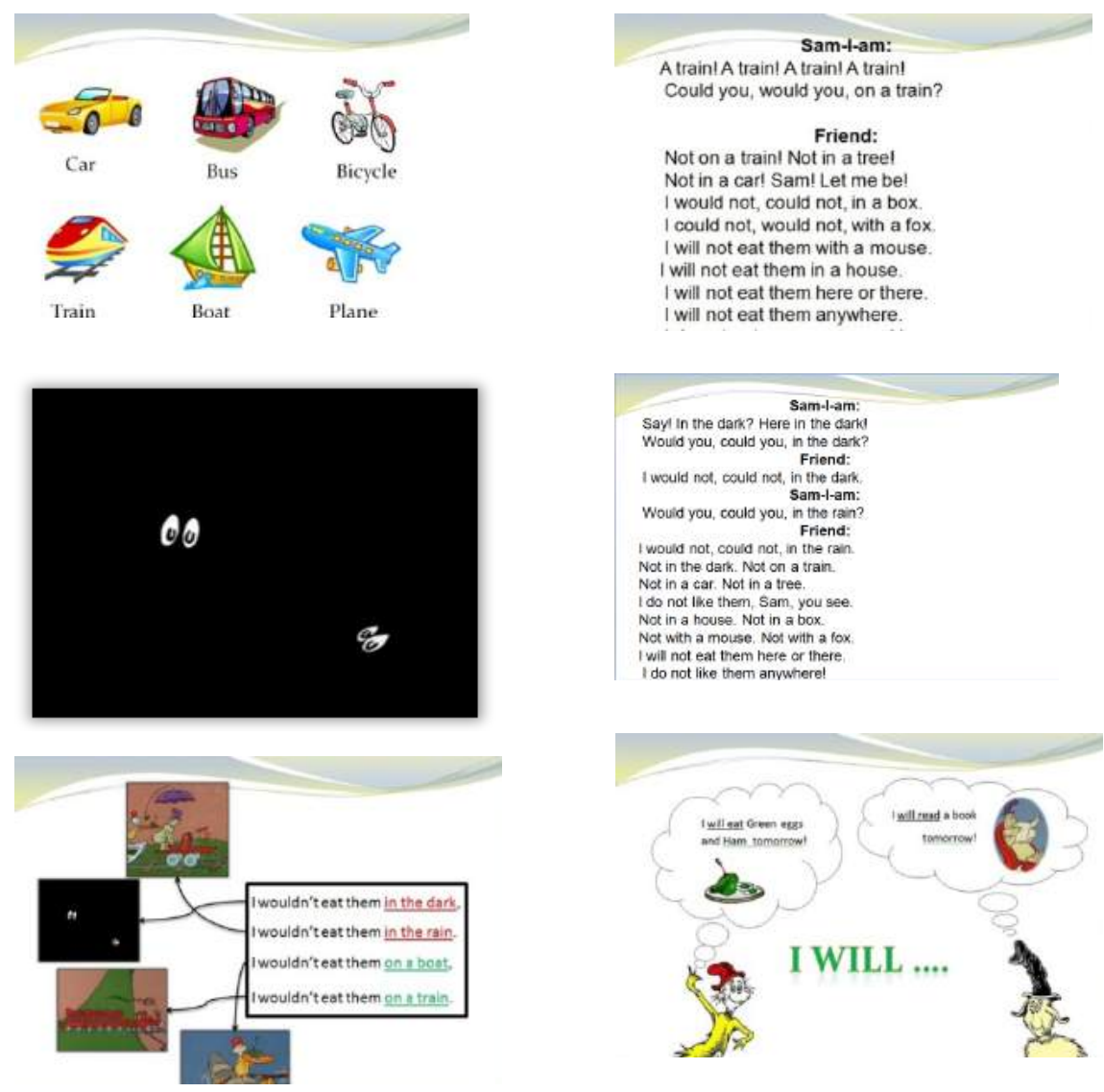


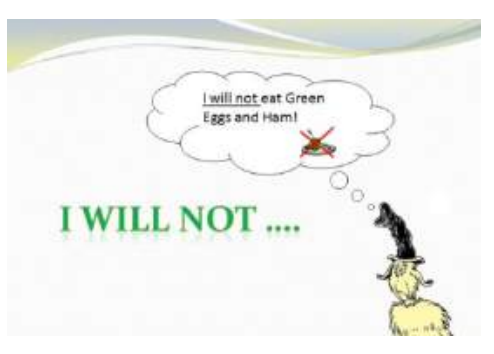

Sam-1-am:
A train! A train! A train! A train! Could you, would you, on a train?

Frienci

Not in a carl Sam! tet mel

I would not, could not, in a box.

I could not, would not, with a fox.

I will not eat them with a mouse.

W. not eat them in a house.

will not eat them here or the

I wi not eat them anywhere.

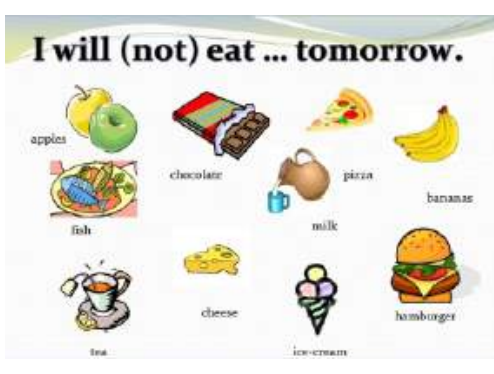

- The worksheet "I would eat ... in ... with a ..." for each child

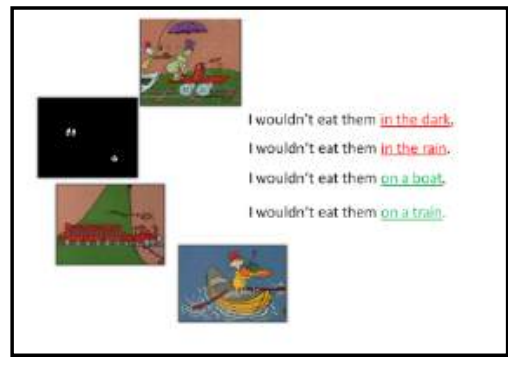

- The worksheet "In/on" for each child

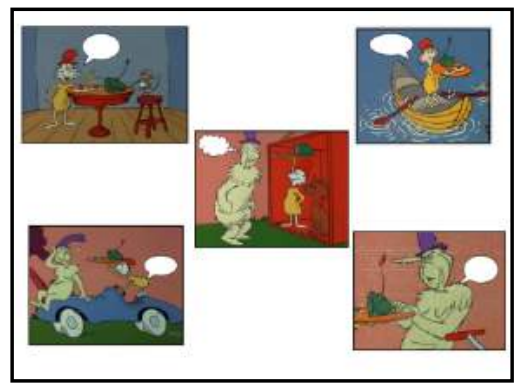




\section{The grammar patterns "I will eat ... / I will not eat"}

\section{Pre-watching discussion}

Ask the children, "What kinds of transport do you know?" Let them answer. Show the first screenshot of PPP \#6 and work on different kinds of transport (car, bus, bicycle, plane, train, boat). Let the children watch the cartoon (part \#5). Give the pre-watching task, "Name kinds of transport from the cartoon."

2. Watching of the cartoon (part \#5)

3. Post-watching activity

Encourage the answer to the pre-watching question ("a train", "a car").

\section{Reading}

Show screenshot \#2 of a dialogue from PPP \#6 on the interactive whiteboard, and give handouts with the same dialogues to each child. Let your pupils translate the phrases "Not on a train! Not in a tree! Not in a car!" Pay attention to the prepositions on and in, and ask the pupils to underline them in their handouts. Say, "Guess the meaning of the phrase 'Let me be!"' Let the children read the dialogue together and role-play it in pairs.

Show screenshot \# 3 from PPP 6 on the interactive whiteboard, point, and say, "Dark." Let your pupils guess the meaning of the word dark. Show screenshot \#4, and give handouts of the same dialogue to each child. Let the children read the dialogue together and role-play it in pairs. Give them the task of underlining the prepositions on and in. Say, "Read the phrases with the prepositions."

Hand out the worksheet "I would eat ... in ... with a ..." to each child. Ask them to match pictures and phrases. Let the children work individually for two minutes. Say, "Let's check." Show screenshot \#5 from PPP \#6. Let the children read the phrases, paying attention to the prepositions.

Show screenshots \#6 and 7. Read the sentences, paying attention to "will / will not." Make sure that the children understand the meaning of the phrases in the bubbles. Show screenshot \#8. Ask the children to find sentences with "will" and read them ("I will not eat them with a mouse," and so forth). Use the last screenshot for individual work with each pupil. Encourage each child to say what he/she will eat tomorrow ("I will eat ... / I will not eat").

Hand out the "In/on" worksheet to each child. Say, "Guess the phrases in the speech balloons. Pretend you are professional actors. Provide the voice of one of the heroes from the cartoon Green Eggs and Ham." 


\section{Lesson 7}

\section{Aims}

- To practice the new grammar "Do you like ...? I like ... / I do not like ...," "Would you like ...? I would (not) like ...," "I would eat ... in ... with a ...," and "I will eat ... / I will not eat."

- To revise words on the topics of food and transport

- To complete the "Green Eggs and Ham Expert" worksheet

\section{Materials}

- Interactive whiteboard

- The cartoon Green Eggs and Ham (part \#6)

- Screenshots from PowerPoint presentation \#7 (PPP \#7)
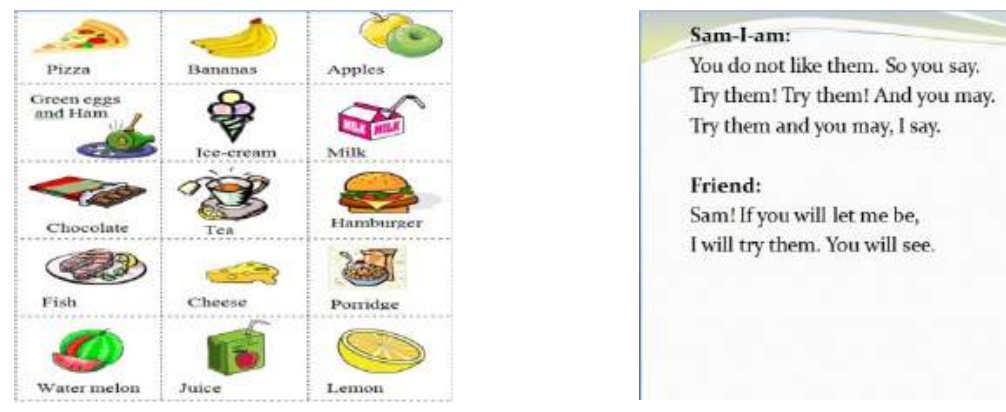
- The "Green Eggs and Ham" board game
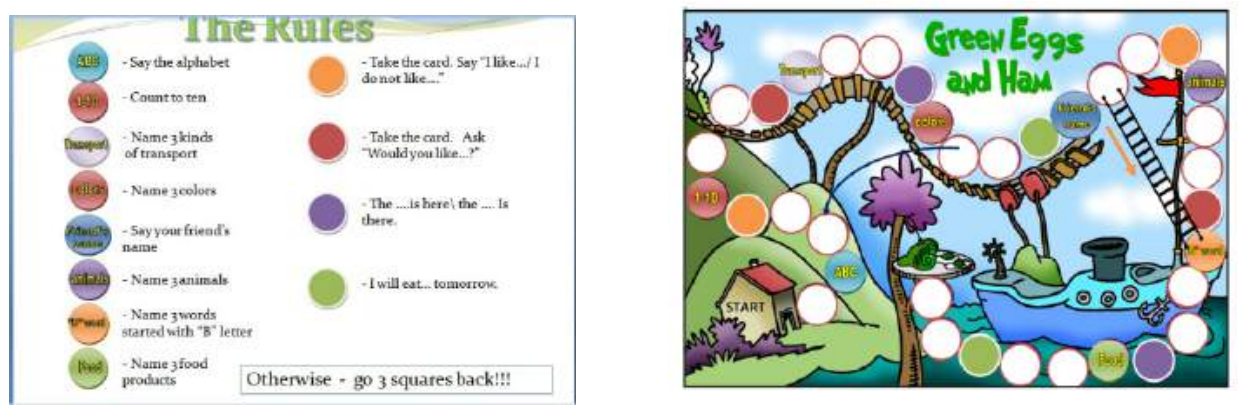

- The worksheet "Green Eggs and Ham Expert" for each child

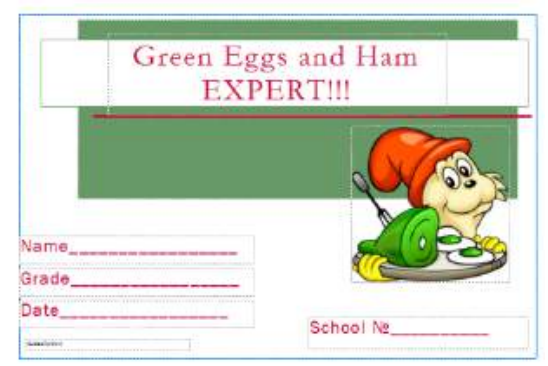

The grammar patterns "Do you like ...? I like ... / I do not like ...," "Would you like ...? I would (not) like ...," "I would eat ... in ... with a ...," and "I will eat ... /

\section{I will not eat"}

\section{Pre-watching discussion}

Show screenshot \# 1 of PPP \# 7, and practice the grammar patterns "Do you like ...? I like ... / I do not like ...," "Would you like ...? I would (not) like ...," "I would eat ... in ... with a ...," and "I will eat ... / I will not eat" with the children.

Ask the children, "Do you want to know the end of the story about green eggs and ham?" Let the children watch the cartoon (part \#6). Ask them the pre-watching question "Does Friend like green eggs and ham?"

2. Watching of the cartoon (part \#6)

3. Post-watching activity

Encourage the answer to the pre-watching question ("Yes, he does"). Ask the emotional question, "Do you like the story about green eggs and ham? Let's read it together." Use screenshots \#2 and 3. 
The board game

Divide the class into groups of four. Hand out the "Green Eggs and Ham Game" board game to each group. Use the screenshot "The Rules." Be sure that pupils understand them and enjoy the game.

Say, "Today we say goodbye to Sam-I-Am and Friend. Do you like the book? You are real experts on the Green Eggs and Ham book now." Hand out the worksheet "Green Eggs and Ham Expert" to each child, and let them fill it in.

Show the final songs of the cartoon, and sing them with the children. 